\title{
Determinan Keikutsertaan Wanita Usia Subur dalam Pemeriksaan IVA di Kabupaten Poso
}

\author{
Lisda Widianti Longgupa \\ Prodi D-III Kebidanan Poso, Jurusan Kebidanan, Poltekkes Kemenkes Palu \\ Email Korespondensi: lisda.santo@gmail.com
}

\section{Article Info}

Article history:

Submitted: 2019-07-11

Accepted: 2019-08-28

Published: 2019-08-31

Keywords:

socio-demographic; attitude; VIA test;

\section{ABSTRACT}

Cervical cancer is a preventable disease, but in fact, women are often found at advanced disease because they do not undergo screening. The purpose of this study was to analyze the relationship between socio-demographic factors, cost, knowledge, and attitude with women's participation in VIA test. The design of this study was cross-sectional. The samples were taken from women who received counseling about cervical cancer during 2016 at districts Health Center by using proportional random sampling. Overall respondents were 198 women. The data were processed and analyzed by using Chi-Square, eta correlation, phi correlation, and multiple logistic regression. Bivariable analysis showed that age ( $p$-value $<0.001)$, education ( $p$-value $<0.001)$, employment ( $p$-value $=0.008)$, income $(p$-value $=0.036$, marital status $(p$-value $=0.010)$, distance $(p$-value $=0.008)$, cost $(p$-value $<0.001$, knowledge ( $p$-value $<0.001)$, and attitude $(p<0.001)$ were significantly related with women's participation in VIA test. Multivariable analysis showed that marital status, knowledge and attitude were significantly related with women's participation in VIA test. Attitude was variable with the largest value of prevalence rate, it was 20,4 and $p$ value $<0,001$. The conclusions that can be taken in this study includes socio-demographic factors were associated with women's participation in VIA test, except parity; the cost has weak relationship with women's participation in VIA test; knowledge has fairly strong relationship with women's participation in VIA test; attitude has fairly strong relationship with women's participation in VIA test and attitude is the most dominant factor related with women's participation in VIA test

\section{ABSTRAK}

Kata Kunci:

Sosial demografi; sikap; pemeriksaan IVA;
Kanker serviks merupakan suatu penyakit yang dapat dicegah, akan tetapi kenyataannya wanita sering ditemukan pada stadium lanjut karena sering tidak menjalani penapisan. Tujuan penelitian ini adalah menganalisis hubungan faktor sosial demografi, biaya, pengetahuan dan sikap dengan keikutsertaan wanita dalam pemeriksaan IVA. Rancangan penelitian yang digunakan adalah potong silang. Sampel diambil dari wanita yang mendapat penyuluhan tentang kanker serviks sejak tahun 2016 di Puskesmas wilayah kerja Dinas Kesehatan Kabupaten Poso dengan menggunakan proportional random sampling. Data dianalisis dengan menggunakan Chi Kuadrat serta regresi logistik ganda. Keseluruhan responden adalah 210 orang. Hasil analisis bivariabel menyatakan terdapat hubungan yang signifikan antara umur $(p=0,048)$, tingkat pendidikan $(p=0,038)$, pekerjaan $(p=0,046)$, pendapatan $(p=0,015)$, status perkawinan $(p=0,010)$, jarak $(p<0,001)$, biaya $(p<0,001)$, pengetahuan $(p<0,024)$ dan sikap $(p<0,001)$ dengan keikutsertaan wanita dalam pemeriksaan IVA. Hasil analisis multivariabel menunjukkan bahwa status perkawinan, pengetahuan dan sikap secara signifikan berhubungan dengan keikutsertaan wanita dalam pemeriksaan IVA. Sikap merupakan variabel dengan nilai OR terbesar yaitu 20,4 dan nilai $p<0,001$. Kesimpulan yang dapat diambil antara lain faktor sosial demografi berhubungan dengan keikutsertaan wanita dalam pemeriksaan IVA, kecuali paritas; biaya mempunyai 
hubungan yang cukup kuat dengan keikutsertaan wanita dalam pemeriksaan IVA; sikap mempunyai hubungan yang kuat dengan keikutsertaan wanita dalam pemeriksaan IVA dan sikap merupakan faktor paling dominan yang berhubungan dengan keikutsertaan wanita dalam pemeriksaan IVA

\section{PENDAHULUAN}

Di Indonesia, kanker serviks merupakan penyakit kanker pada perempuan urutan kedua setelah kanker payudara. ${ }^{1}$ Pada tiga dekade terakhir ini, kasus kanker serviks meningkat pada usia lebih muda atau dibawah 30 tahun. Berdasarkan data Riskesdas (2013), prevalensi kanker di Indonesia adalah 1,4 per 1000 penduduk, sedangkan kanker serviks merupakan kanker dengan prevalensi kedua tertinggi di Indonesia sebesar $0,8 \%$ atau sekitar 98.692 penduduk. $^{2}$

Tingginya angka morbiditas dan mortalitas kanker serviks menurut WHO disebabkan karena keterlambatan dalam pengobatan. ${ }^{3}$ Pasien biasanya datang ke rumah sakit sudah dalam kondisi stadium lanjut dan terlambat untuk diobati. Ini terjadi karena terlambatnya deteksi dini kanker dan kurangnya pengetahuan masyarakat mengenai gejala kanker serviks. Menyikapi hal ini, pemerintah melalui Kementerian Kesehatan mencanangkan program deteksi dini kanker serviks metode IVA di Puskesmas.

Keikutsertaan merupakan respon atau reaksi terhadap stimulus atau rangsangan yang dalam pelaksanaannya bergantung pada karakteristik atau faktorfaktor lain dari orang yang bersangkutan, artinya walaupun stimulusnya sama bagi beberapa orang namun respon tiap orang berbeda-beda. Keikutsertaan untuk ikut serta menjalani pemeriksaan penapisan dipengaruhi oleh beberapa faktor, antara lain faktor sosial demografi, biaya, pengetahuan dan sikap wanita itu sendiri. ${ }^{4}$

Beberapa penelitian menyatakan faktor sosial demografi berhubungan dengan keikutsertaan penapisan kanker serviks. Keikutsertaan wanita dalam penapisan kanker serviks paling sering dilakukan oleh wanita umur 20-29 tahun, pendidikan yang baik, wanita yang menikah dan sudah mempunyai anak, bahkan wanita dengan pendidikan yang lebih tinggi, pernah hamil dan sudah menikah lebih patuh dalam menjalani pengobatan lanjutan. ${ }^{5}$

Rendahnya angka cakupan deteksi dini IVA ini disebabkan karena rendahnya kesadaran perempuan Indonesia untuk melakukan deteksi dini kanker serviks. Cakupan deteksi dini di Indonesia kurang dari lima persen $(2,45 \%$,) sehingga banyak kasus kanker serviks ditemukan sudah stadium lanjut dan seringkali menyebabkan kematian pada wanita. Berdasarkan studi pendahuluan di salah satu Puskesmas di Kabupaten Poso, melalui wawancara dengan pemegang program IVA diketahui bahwa faktor yang menjadi hambatan perempuan tidak melakukan deteksi dini kanker serviks adalah kurangnya pengetahuan akan bahaya kanker, pendidikan yang kurang atau kurangnya informasi tentang penyakit kanker dan deteksi dininya, sehingga muncul rasa takut, cemas, ataupun malu bila hasilnya positif dan memilih untuk menghindarinya. Kurangnya promosi kesehatan dan belum maksimalnya perluasan informasi deteksi dini kanker serviks metode IVA ditanggung oleh JKN juga menjadi hambatan seseorang melakukan IVA.

Penelitian tentang faktor yang berhubungan dengan keikutsertaan penapisan kanker serviks yang sudah dilakukan masih bersifat terpisah-pisah dan belum ada penelitian yang menggabungkan faktor-faktor tersebut dalam satu penelitian. Oleh karena alasan tersebut peneliti tertarik untuk meneliti determinan faktor keikutsertaan wanita usia subur dalam pemeriksaan IVA, selain itu diwilayah ini juga belum pernah 
dilakukan penelitian yang serupa. Tujuan penelitian ini adalah untuk menganalisis hubungan antara faktor sosial demografi, biaya, pengetahuan, sikap dengan keikutsertaan wanita dalam pemeriksaan IVA serta menganalisis faktor yang paling dominan berhubungan dengan keikutsertaan wanita dalam pemeriksaan IVA.

\section{METODE PENELITIAN}

Desain yang digunakan dalam penelitian ini adalah cross sectional, yang dilakukan di wilayah kerja Puskesmas Kabupaten Poso pada bulan Mei-Oktober 2017. Populasi dalam penelitian ini adalah wanita yang mendapatkan penyuluhan tentang penapisan kanker serviks dengan metode IVA sejumlah 458 orang. Teknik pengambilan sampel pada penelitian ini adalah menggunakan proportional random sampling. Sampel ditentukan berdasarkan wilayah Puskesmas yang diberikan penyuluhan pemeriksaan IVA pada tahun 2016. Dalam penelitian ini jumlah sampel dihitung dengan menggunakan rumus besar sampel untuk beda 2 proporsi , didapatkan besar sampel 210 orang, kemudian dilakukan teknik Simple Random Sampling. Teknik pengumpulan data dalam penelitian ini menggunakan kuesioner.Pengolahan data meliputi editing, coding, processing dan cleaning. Uji yang dilakukan adalah regresi logistik ganda.

\section{HASIL PENELITIAN}

Setelah data penelitian dianalisis maka diperoleh hasil sebagai berikut:

Tabel 1: Hubungan Faktor Sosial Demografi dengan Keikutsertaan Wanita dalam Pemeriksaan IVA

\begin{tabular}{|c|c|c|c|c|c|c|c|c|}
\hline \multirow[t]{3}{*}{$\begin{array}{c}\text { Faktor } \\
\text { Sosial Demografi }\end{array}$} & \multicolumn{6}{|c|}{$\begin{array}{c}\text { Keikutsertaan dalam Pemeriksaan } \\
\text { IVA }\end{array}$} & \multirow[t]{3}{*}{$x^{2}$} & \multirow[t]{3}{*}{ Nilai $p$} \\
\hline & \multicolumn{2}{|c|}{ Tidak } & \multicolumn{2}{|c|}{ Ya } & \multicolumn{2}{|c|}{ Total } & & \\
\hline & $\mathbf{n}$ & $\%$ & $\mathbf{n}$ & $\%$ & $\mathbf{n}$ & $\%$ & & \\
\hline \multicolumn{9}{|l|}{ Umur } \\
\hline$-20-29$ tahun & 24 & 17 & 117 & 83 & 141 & 100 & 7,898 & 0,048 \\
\hline - 30-39 tahun & 16 & 32,7 & 33 & 67,3 & 49 & 100 & & \\
\hline - 40-49 tahun & 6 & 35,3 & 11 & 64,7 & 17 & 100 & & \\
\hline - 50-60 tahun & 0 & 100 & 3 & 100 & 3 & 100 & & \\
\hline \multicolumn{9}{|l|}{ Tingkat pendidikan } \\
\hline - Rendah & 12 & 35,3 & 22 & 64,7 & 34 & 100 & 6,554 & 0,038 \\
\hline - Menengah & 10 & 13,7 & 63 & 86,3 & 73 & 100 & & \\
\hline - Tinggi & 24 & 23,3 & 79 & 76,7 & 103 & 100 & & \\
\hline \multicolumn{9}{|l|}{ Pekerjaan } \\
\hline - Tidak bekerja & 37 & 26,2 & 104 & 73,8 & 141 & 100 & 4,717 & 0,046 \\
\hline \multicolumn{9}{|l|}{ Pendapatan } \\
\hline$-<$ UMR & 39 & 26,9 & 106 & 73,1 & 145 & 100 & 6,824 & 0,015 \\
\hline - $\geq$ UMR & 7 & 10,8 & 58 & 89,2 & 65 & 100 & & \\
\hline \multicolumn{9}{|l|}{ Paritas } \\
\hline - Nulipara & 3 & 27,3 & 8 & 72,7 & 11 & 100 & 4,332 & 0,228 \\
\hline - Primipara & 11 & 32,4 & 23 & 67,6 & 34 & 100 & & \\
\hline $\begin{array}{l}\text { - Multipara+ } \\
\text { grandemulti }\end{array}$ & 32 & 20,1 & 133 & 79,9 & 165 & 100 & & \\
\hline \multicolumn{9}{|l|}{ Status perkawinan } \\
\hline - Cerai + janda & 3 & 100 & 0 & 0 & 3 & 100 & 10,851 & 0,010 \\
\hline - Kawin & 43 & 20,8 & 164 & 79,2 & 207 & 100 & & \\
\hline \multicolumn{9}{|l|}{$\begin{array}{l}\text { Jarak rumah dengan } \\
\text { tempat pemeriksaan }\end{array}$} \\
\hline - Jauh & 12 & 54,5 & 10 & 45,5 & 22 & 100 & 15,305 & $<0,001$ \\
\hline - Dekat & 34 & 18,1 & 154 & 81,9 & 188 & 100 & & \\
\hline
\end{tabular}


Rentang umur 40-49 tahun lebih banyak yang tidak menjalani pemeriksaan IVA $(35,3 \%)$ dan rentang umur 20-29 tahun lebih banyak yang menjalani pemeriksaan $(83 \%)$. Hasil perhitungan statistik menyatakan terdapat hubungan yang sangat signifikan antara umur dengan keikutertaan wanita dalam pemeriksaan IVA $(p<0,001)$.

Tingkat pendidikan yang rendah banyak yang tidak menjalani pemeriksaan IVA $(35,3 \%)$, dan tingkat pendidikan menengah lebih banyak yang menjalani pemeriksaan $(86,3 \%)$. Hasil perhitungan statistik menyatakan menyatakan terdapat hubungan yang sangat signifikan antara tingkat pendidikan dengan keikutertaan wanita dalam pemeriksaan IVA $(p<0,001)$.

Status tidak bekerja banyak yang tidak menjalani pemeriksaan IVA $(26,2 \%)$, dan status bekerja lebih banyak yang menjalani pemeriksaan (73,8\%). Hasil perhitungan statistik dengan menggunakan Chi Kuadrat menyatakan terdapat hubungan yang sangat signifikan antara pekerjaan dengan keikutertaan wanita dalam pemeriksaan IVA $(p=0,046)$.

Pendapatan yang kurang dari UMR banyak yang tidak menjalani pemeriksaan IVA $(26,9 \%)$, dan responden dengan pendapatan lebih dari atau sama dengan UMR banyak yang menjalani pemeriksaan $(89,2 \%)$. Hasil perhitungan statistik menyatakan terdapat hubungan yang signifikan antara pendapatan dengan keikutertaan wanita dalam pemeriksaan IVA $(p=0,015)$.

Berdasarkan paritas, nullipara banyak yang tidak menjalani pemeriksaan IVA $(27,3 \%)$ dan multipara lebih banyak yang menjalani pemeriksaan $(79,9 \%)$. Hasil perhitungan statistik menyatakan tidak terdapat hubungan yang signifikan antara paritas dengan keikutertaan wanita dalam pemeriksaan IVA $(p>0,05)$.

Berdasarkan status perkawinannya, wanita dengan status tidak kawin (janda/cerai) banyak yang tidak menjalani pemeriksaan IVA (100\%), dan status kawin lebih banyak yang menjalani pemeriksaan $(79,2 \%)$. Hasil perhitungan statistik dengan menggunakan Chi Kuadrat menyatakan terdapat hubungan yang signifikan antara status perkawinan dengan keikutertaan wanita dalam pemeriksaan IVA $(\mathrm{p}=0,010)$.

Jarak rumah yang jauh dari tempat pemeriksaan banyak yang tidak menjalani pemeriksaan IVA (54,5\%), dan jarak yang dekat banyak menjalani pemeriksaan $(81,9 \%)$. Hasil perhitungan statistik menyatakan terdapat hubungan yang sangat signifikan $(p=0,000)$ antara jarak dengan keikutertaan wanita dalam pemeriksaan IVA.

Tabel 2: Hubungan Biaya dengan Keikutsertaan Wanita dalam Pemeriksaan IVA

\begin{tabular}{|c|c|c|c|c|c|c|c|c|}
\hline \multirow[t]{3}{*}{ Variabel } & \multicolumn{6}{|c|}{$\begin{array}{c}\text { Keikutsertaan Wanita dalam } \\
\text { Pemeriksaan IVA }\end{array}$} & \multirow[t]{3}{*}{$x^{2}$} & \multirow[t]{3}{*}{ Nilai $p$} \\
\hline & \multicolumn{2}{|c|}{ Tidak } & \multicolumn{2}{|c|}{ Ya } & \multicolumn{2}{|c|}{ Total } & & \\
\hline & $\mathbf{n}$ & $\%$ & $\mathbf{n}$ & $\%$ & $\mathbf{n}$ & $\%$ & & \\
\hline \multicolumn{9}{|l|}{ Biaya } \\
\hline Bayar & 11 & 91,7 & 1 & 8,3 & 12 & 100 & \multirow[t]{3}{*}{36,208} & \multirow[t]{2}{*}{$<0,001$} \\
\hline Gratis & 35 & 17,7 & 163 & 82,3 & 198 & 100 & & \\
\hline \multicolumn{8}{|l|}{ Pengetahuan } & \\
\hline Rendah & 19 & 33,3 & 38 & 66,7 & 57 & 100 & \multirow[t]{2}{*}{5,973} & \multirow[t]{2}{*}{0,024} \\
\hline Tinggi & 27 & 17,6 & 126 & 82,4 & 153 & 100 & & \\
\hline \multicolumn{9}{|l|}{ Sikap } \\
\hline Negatif & 24 & 70,6 & 10 & 29,4 & 34 & 100 & \multirow[t]{2}{*}{56,206} & \multirow[t]{2}{*}{$<0,001$} \\
\hline Positif & 22 & 12,5 & 154 & 87,5 & 100 & 100 & & \\
\hline
\end{tabular}


Tabel 2 menunjukkan bahwa wanita yang harus membayar dalam menjalani pemeriksaan banyak yang tidak menjalani pemeriksaan IVA $(91,7 \%)$, sedangkan yang gratis lebih banyak yang menjalani pemeriksaan (82,3\%). Hasil perhitungan statistik menyatakan terdapat hubungan yang sangat signifikan antara biaya dengan keikutsertaan wanita dalam pemeriksaan IVA $(p<0,001)$.

Tabel 2 menunjukkan bahwa pengetahuan yang rendah banyak yang tidak menjalani pemeriksaan IVA $(33,3 \%)$, sedangkan pengetahuan yang tinggi lebih banyak yang menjalani pemeriksaan $(82,4 \%)$. Hasil perhitungan statistik menyatakan terdapat hubungan yang sangat signifikan antara pengetahuan dengan keikutsertaan wanita dalam pemeriksaan IVA $(p=0,024)$.

Tabel 2 menunjukkan bahwa sikap yang negatif banyak yang tidak menjalani pemeriksaan IVA $(70,6 \%)$, sedangkan sikap yang positif lebih banyak yang menjalani pemeriksaan $(87,5 \%)$. Hasil perhitungan statistik menyatakan terdapat hubungan yang sangat signifikan antara sikap dengan keikutsertaan wanita dalam pemeriksaan IVA $(p<0,001)$

Tabel 3: Hubungan Faktor Sosial Demografi, Biaya, Pengetahuan dan Sikap dengan Keikutsertaan Wanita dalam Pemeriksaan IVA

\begin{tabular}{clc}
\hline No & \multicolumn{1}{c}{ Variabel } & Nilai $\mathbf{p}$ \\
\hline 1 & Umur & 0,048 \\
2 & Pendidikan & 0,038 \\
3 & Pekerjaan & 0,046 \\
4 & Pendapatan & 0,015 \\
5 & Status perkawinan & 0,010 \\
6 & Jarak rumah dengan tempat pemeriksaan & $<0,001$ \\
7 & Biaya & $<0,001$ \\
8 & Pengetahuan & 0,024 \\
9 & Sikap & $<0,001$ \\
\hline
\end{tabular}

Setelah tahap pemilihan variabel untuk analisis multivariabel, tahap selanjutnya adalah melakukan analisis multivariabel secara bersama-sama. Variabel yang valid dalam model multivariabel adalah variabel yang mempunyai nilai $p$ kurang dari 0,05 , apabila ada variabel yang nilai $p$ lebih dari 0,05 maka variabel tersebut dikeluarkan dari model. Pengeluaran variabel dilakukan secara bertahap dimulai dari nilai $p$ yang terbesar. Hasil akhir analisis multivariabel dengan menggunakan regresi logistik ganda dapat dilihat pada tabel berikut.

Tabel 4: Hubungan Faktor Sosial Demografi, Biaya, Pengetahuan dan Sikap dengan Keikutsertaan Wanita dalam Pemeriksaan IVA

\begin{tabular}{clcccc}
\hline No & Variabel & B & SE $(\boldsymbol{\beta})$ & Nilai $\mathbf{p}$ & OR $(\mathbf{9 5} \% \mathbf{C l})$ \\
\hline 1 & Pendapatan & -2.473 & 0,806 & 0,002 & $0,084(0,138-0,780)$ \\
2 & Jarak & 1,723 & 0,660 & 0,009 & $5,602(2,171-13,608)$ \\
3 & Biaya & $-5,210$ & 1,136 & 0,000 & $0,020(0,002-0,156)$ \\
4 & Sikap & 3,017 & 0,552 & 0,000 & $20,432(7,092-39,797)$ \\
& Konstanta & 6,064 & 3,108 & & \\
\hline
\end{tabular}

Keterangan: Akurasi model $=82,3 \%$

Tabel 4 menunjukkan bahwa hasil pada analisis regresi logistik ganda terdapat empat variabel yang berhubungan secara signifikan dengan keikutsertaan wanita dalam pemeriksaan IVA, variabel ini adalah pendapatan, jarak, biaya dan sikap. Hal ini ditunjukkan dengan nilai $p<0,05$. Variabel sikap mempunyai odds ratio $(\mathrm{OR})$ yang paling besar yaitu 20,432 serta nilai $p$ pada variabel sikap merupakan nilai $p$ yaitu 0,000 


\section{PEMBAHASAN}

\section{Faktor Sosial Demografi}

\section{A. Pendapatan}

Pendapatan keluarga kurang dari UMR menyebabkan banyak wanita yang tidak menjalani pemeriksaan IVA $(26,9 \%)$, sedangkan pendapatan yang lebih dari atau sama dengan UMR menyebabkan wanita menjalani pemeriksaan $(89,2 \%)$. Hasil uji statistik menemukan bahwa terdapat hubungan yang signifikan antara pendapatan keluarga dengan keikutsertaan wanita dalam pemeriksaan IVA $(p=0,036)$. Pendapatan keluarga lebih dari atau sama dengan UMR menjadi faktor pendorong seorang wanita untuk menjalani pemeriksaan IVA.

Tingginya pendapatan sering dikaitkan dengan tingginya kesempatan bagi seseorang untuk mendapat pendidikan yang lebih baik serta kemampuan untuk mendapatkan pelayanan kesehatan yang lebih baik.

Pendapatan yang tinggi juga dikaitkan dengan kemudahan seorang wanita dalam mendapat akses pelayanan kesehatan karena kemampuan wanita tersebut dalam membayar total biaya yang diperlukan dalam suatu pelayanan kesehatan. Wanita dengan pendapatan yang rendah biasanya lebih memprioritaskan pemanfaatan pendapatan yang diperolehnya untuk kebutuhan sehari-hari atau kebutuhan primer daripada untuk membayar biaya yang diperlukan dalam suatu pemeriksaan. ${ }^{6}$

\section{B. Jarak Rumah dengan Tempat Pemeriksaan}

Penelitian ini menunjukkan bahwa jarak rumah yang dekat dengan tempat pemeriksaan menyebabkan wanita cenderung untuk menjalani pemeriksaan IVA $(52,8 \%)$ dan terdapat hubungan yang sangat signifikan ( $\mathrm{A}$ $<0,001)$ antara jarak dengan keikutsertaan wanita dalam pemeriksaan IVA. Hasil analisis multivariabel menunjukkan bahwa status perkawinan secara signifikan $(p=0,009)$ berhubungan dengan keikutsertaan wanita dalam pemeriksaan IVA (OR=5.602; 95\% Cl=2,171-13.608)

Salah satu hambatan dalam menjalani penapisan kanker serviks adalah jarak rumah dengan tempat pemeriksaan. Jarak rumah dengan tempat pemeriksaan erat kaitannya dengan keikutsertaan seseorang dalam suatu program kesehatan, hal ini terkait dengan keterjangkauan atau kemudahan dalam pencapaian tempat pemeriksaan. Walaupun jarak tempat tinggal ke lokasi pemeriksaan relatif dekat, namun kesulitan transportasi merupakan hambatan dalam pencapaiannya ke lokasi pemeriksaan, sehingga jarak akan berpengaruh pada keikutsertaan seseorang dalam menjalani program penapisan yang dalam hal ini dalam dengan metode pemeriksaan IVA.

\section{Biaya}

Wanita yang harus mengeluarkan biaya (bayar) lebih banyak yang tidak menjalani pemeriksaan IVA $(91,7 \%)$ sedangkan tidak adanya biaya (gratis) menyebabkan wanita banyak yang menjalani pemeriksaan (82,3\%). Analisis statistik yang dilakukan menunjukkan bahwa terdapat hubungan yang sangat signifikan $(p<0,001)$ antara biaya dengan keikutsertaan wanita dalam pemeriksaan IVA.

Ada atau tidaknya biaya yang dikeluarkan akan menjadi pertimbangan seseorang dalam menjalani penapisan kanker serviks. Biaya yang harus dikeluarkan dalam menjalani penapisan antara lain adalah biaya yang terkait 
dengan perjalanan serta biaya untuk pemeriksaan. Biaya yang dikeluarkan ini tentunya akan mengurangi pendapatan keluarga yang telah didapatkan. Wanita dengan pendapatan keluarga yang kurang sering tidak mengikuti suatu penapisan kanker serviks, terutama jika harus mengeluarkan atau membayar dengan sejumlah uang untuk menjalani pemeriksaan tersebut (6). ${ }^{6}$ Penelitian yang telah dilakukan di Maharashtra India menyatakan bahwa biaya pemeriksaan yang gratis serta tidak adanya biaya transportasi dapat membantu meningkatkan keikutsertaan wanita untuk menjalani pemeriksaan IVA.

D. Sikap

Hasil penelitian menunjukkan wanita dengan sikap negatif kanker sebesar $70,6 \%$ tidak menjalani pemeriksaan IVA, sedangkan yang memiliki sikap positif kanker sebesar $87,5 \%$ menjalani pemeriksaan. Analisis bivariabel menunjukkan terdapat hubungan yang sangat signifikan $(p<0,001)$ antara sikap dengan keikutsertaan wanita dalam pemeriksaan IVA.

Analisis multivariabel menunjukkan bahwa sikap secara sangat signifikan $(p=0,000)$ berhubungan dengan keikutsertaan wanita dalam pemeriksaan IVA. Sikap yang negatif berisiko 20,432 kali untuk tidak menjalani pemeriksaan IVA dibandingkan dengan sikap yang positif $(95 \% \mathrm{Cl}=$ 7,092-39797).

Penelitian ini menemukan sebanyak 98 wanita (49,49\%) mempunyai sikap yang negatif. Sikap wanita yang menganggap penapisan kanker serviks tidak perlu dilakukan jika tidak ada gejala serta anggapan bahwa penapisan kanker serviks merupakan suatu hal yang memalukan perlu di atasi. Beberapa penelitian membuktikan bahwa sikap ini sering menghambat wanita untuk ikut serta menjalani penapisan. Hal ini memerlukan adanya pemberian informasi yang cukup kepada masyarakat khususnya wanita. ${ }^{7}$

Penyuluhan yang telah dilakukan diharapkan dapat memberikan gambaran tentang kanker serviks dan penapisan kanker serviks kepada masyarakat, dengan demikian sikap negatif kanker seperti persepsi tidak perlu menjalani penapisan kanker serviks jika tidak ada gejala serta persepsi lebih baik tidak mengetahui suatu kelainan ditubuhnya daripada hidup dalam kecemasan dapat dihindari dan pada akhirnya dengan memiliki sikap yang positif maka wanita mau menjalani penapisan kanker serviks. ${ }^{8}$

\section{SIMPULAN DAN SARAN}

Berdasarkan hasil penelitian dapat dibuat simpulan Faktor sosial demografi yaitu pendapatan, jarak, biaya dan sikap berhubungan dengan keikutsertaan wanita dalam pemeriksaan IVA. Sikap merupakan faktor paling dominan yang berhubungan dengan keikutsertaan wanita dalam menjalani pemeriksaan IVA. Penelitian ini menyarankan agar Dins Kesehatan Hendaknya memberi informasi tentang kanker serviks dan cara pencegahannya kepada masyarakat melalui media massa, seperti media cetak ataupun media elektronik. Perlu menggalakkan kembali pemberian penyuluhan tentang kanker serviks dan cara pencegahannya dengan menitikberatkan kepada wanita umur 20-39 tahun dan status perkawinan cerai atau janda. Hendaknya seluruh tenaga kesehatan khususnya bidan dapat melakukan pemeriksaan IVA dengan mengikuti pelatihan IVA sehingga masyarakat dapat dengan mudah menjangkau tempat pelayanan penapisan kanker serviks dan juga dapat meminimalisasi biaya yang harus dikeluarkan. 


\section{DAFTAR PUSTAKA}

1. Oktaviana MN. Hubungan antara Persepsi Kerentanan Individu, Keseriusan Penyakit, Manfaat dan Hambatan dengan Penggunaan Skrining IVA pada WUS. Universitas Sebelas Maret; 2015.

2. Kementerian Kesehatan R.I. Riset Kesehatan Dasar 2013. Jakarta: Kementerian Kesehatan R.I.; 2013.

3. World Health Organization. IARC Handbooks of Cancer Prevention: Cervical Cancer Screening [Internet]. 10th ed. Lyon: IARC Press; 2005. Available from: http://gigapedia.com/items:links?eid=nXa\%2F5gAJPj\%2Fd5wiYebMSSGBBbZUgonjJI BR931XFI6I\%3D

4. Gao W, Paterson J, DeSouza R, Lu T. Demographic Predictors of Cervical Cancer Screening in Chinese Women in New Zealand. N Z Med J [Internet]. 2008 Jul 4;121(1277):8-17. Available from: http://www.ncbi.nlm.nih.gov/pubmed/18677326

5. Nene B, Jayant K, Arrossi S, Shastri S, Budukh A, Hingmire S, et al. Determinants of Women's Participation in Cervical Cancer Screening Trail, Maharashtra, India. Bull World Health Organ [Internet]. 2007 Apr 1;85(4):264-72. Available from: http://www.who.int/bulletin/volumes/85/4/06-031195.pdf

6. Winkler J, Bingham A, Coffey P, Penn Handwerker W. Women's Participation in a Cervical Cancer Screening Program in Northern Peru. Health Educ Res [Internet]. 2007 Jan 17;23(1):10-24. Available from: https://academic.oup.com/her/articlelookup/doi/10.1093/her/cyl156

7. Sutton S, Rutherford C. Sociodemographic and Attitudinal Correlates of Cervical Screening Uptake in a National Sample of Women in Britain. Soc Sci Med [Internet]. 2005 Dec;61(11):2460-5. Available from: https://linkinghub.elsevier.com/retrieve/pii/S0277953605003874

8. Winkel WS. Psikologi Pengajaran. Yogyakarta: Media Abadi; 2015. 117-8, 272-88 p. 